\begin{abstract}
Iranica
Abstracta Iranica Revue bibliographique pour le domaine irano-aryen

Volume 32-33 | 2013

Comptes rendus des publications de 2009-2010
\end{abstract}

\title{
Finbarr B. Flood. Objects of Translation: Material Culture and Medieval "Hindu-Muslim" Encounter
}

\section{Fabrizio Speziale}

\section{(2) OpenEdition}

1 Journals

\section{Édition électronique}

URL : http://journals.openedition.org/abstractairanica/40627

DOI : 10.4000/abstractairanica.40627

ISSN : 1961-960X

Éditeur :

CNRS (UMR 7528 Mondes iraniens et indiens), Éditions de l'IFRI

\section{Édition imprimée}

Date de publication : 1 décembre 2013

ISSN : 0240-8910

\section{Référence électronique}

Fabrizio Speziale, «Finbarr B. Flood. Objects of Translation: Material Culture and Medieval "Hindu-Muslim" Encounter », Abstracta Iranica [En ligne], Volume 32-33 | 2013, document 273, mis en ligne le 01 juillet 2016, consulté le 03 octobre 2020. URL : http://journals.openedition.org/abstractairanica/40627 DOI : https://doi.org/10.4000/abstractairanica.40627

Ce document a été généré automatiquement le 3 octobre 2020.

Tous droits réservés 


\title{
Finbarr B. Flood. Objects of
} Translation: Material Culture and Medieval "Hindu-Muslim" Encounter

\author{
Fabrizio Speziale
}

\section{RÉFÉRENCE}

Finbarr B. Flood. Objects of Translation: Material Culture and Medieval "Hindu-Muslim"

Encounter. Princeton - Oxford, Princeton University Press, p. xv-366, 180 fig.

1 Cet ouvrage offre une contribution importante à l'étude des interactions entre les cultures et les sociétés musulmanes et hindoues à l'époque pré-moghole. Ce volume examine notamment ces interactions à travers les objets, l'art, la monnaie, le vêtement, les monuments, la sculpture, et se trouve accompagné d'une riche iconographie en noir et blanc. L'ouvrage se concentre sur la période médiévale et sur les dynasties musulmanes et hindoues qui régnèrent dans la région comprise entre l'Afghanistan et l'Inde du nord.

\section{AUTEURS}

\section{FABRIZIO SPEZIALE}

Université Sorbonne Nouvelle-Paris 3/Mondes iranien et indien, Paris 